\title{
PENGEMBANGAN PERANGKAT PEMBELAJARAN DENGAN PEMECAHAN MASALAH UNTUK MELATIH KEMAMPUAN BERPIKIR KREATIF SISWA KELAS IV SD MATERI PECAHAN
}

\author{
Sri Widadi ${ }^{1}$, Mega Teguh Budiarto ${ }^{2}$, Tatag Yuli Eko Siswono ${ }^{3}$ \\ Pendidikan Dasar, Program Pascasarjana Universitas Negeri Surabaya \\ email: sriwidadi48@yahoo.com
}

\begin{abstract}
Abstrak
Penelitian ini bertujuan untuk (1) menghasilkan perangkat pembelajaran dengan pemecahan masalah yang layak untuk melatih kemampuan berpikir kreatif siswa kelas IV SD materi pecahan (2) mendeskripsikan keefektifan pembelajaran dengan menggunakan perangkat pembelajaran dengan pemecahan masalah untuk melatih kemampuan berpikir kreatif siswa kelas IV SD materi pecahan.

Dari hasil analisis deskriptif ujicoba penelitian Pengembangan Perangkat Pembelajaran Dengan pemecahan masalah untuk melatih kemampuan berpikir kreatif siswa kelas IV SD materi pecahan menghasilkan perangkat pembelajaran yang layak karena memenuhi: (1) hasil belajar pretes dan postes siswa meningkat, (2) kemampuan berpikir kreatif siswa meningkat, (3) Penilaian autentik siswa ketuntasan mencapai 97\%, (4) kategori sangat baik untuk kemampuan guru mengelola pembelajaran, (5) kategori sangat baik untuk respon siswa terhadap perangkat dan kegiatan pembelajaran, dan (6) kategori sangat baik untuk Aktivitas siswa selama pembelajaran.

Dari hasil analisis deskriptif penelitian eksperimen pada Perangkat Pembelajaran Dengan pemecahan masalah untuk melatih kemampuan berpikir kreatif siswa kelas IV SD materi pecahan menghasilkan perangkat pembelajaran efektif karena memenuhi: (1) kategori sangat baik untuk kemampuan guru mengelola pembelajaran, (2) kategori sangat baik untuk respon siswa terhadap perangkat dan kegiatan pembelajaran, (3) kategori sangat baik untuk Aktivitas siswa selama pembelajaran, (4) Peningkatan hasil belajar dan kemampuan berpikir kreatif kelas eksperimen lebih tinggi dibanding kelas kontrol yang dibuktikan dengan analisis statistik. Berdasarkan hasil temuan di atas dapat diambil kesimpulan bahwa perangkat pembelajaran dengan pemecahan masalah untuk melatih kemampuan berpikir kreatif siswa kelas IV materi pecahan layak dan efektif.
\end{abstract}

Kata-kata Kunci: pengembangan perangkat, pemecahan masalah, berpikir kreatif, materi pecahan.

\begin{abstract}
This research aims to (1) produce learning device with problem solving to practice creative thinking abilities of students fourth grade material of fractions (2) describe the effectiveness of learning by using learning to problem-solving device to train the students' ability to think creatively fourth grade material of fractions.

From the results of the descriptive analysis of trials Development of learning devices solutions to train the students to think creatively fourth grade material of fractions produce a viable learning device because it meets: (1) the results of pretest and posttest student learning increase, (2) the ability of creative thinking of students increase (3) Authentic assessment of students completeness reached $97 \%$, (4) excellent category for observation teacher's ability to manage learning, (5) excellent category for the students' response to the device and learning activities, and (6) the excellent category for student activity during learning.

Based on the results of the descriptive analysis of experimental research on Learning Device troubleshooting to train the students' ability to think creatively fourth grade material fractions produce effective learning tools because it meets: (1) very good category for observation teacher's ability to manage learning, (2) the excellent category for student response of the device and learning activities, (3) the category is very good for students during learning activities, (4) improved learning outcomes experimental class is higher than the control class, and (5) increased ability to think creatively; experimental class is higher than the control class.

Based on the findings of the above it can be concluded that learning with problem solving device to train the students' ability to think creatively fourth grade material of fractions is feasible and effective .
\end{abstract}

Keywords: development device, problem solving, creative thinking, material of fractions 


\section{PENDAHULUAN}

Orientasi mata pelajaran matematika saat ini diupayakan untuk membekali peserta didik dengan kemampuan berpikir tingkat tinggi termasuk berpikir kreatif. Hal ini dinyatakan dalam Dokumen Kurikulum Tingkat Satuan Pendidikan (2006:416) bahwa mata pelajaran matematika perlu diberikan kepada semua peserta didik mulai dari sekolah dasar untuk membekali peserta didik dengan kemampuan berpikir logis, analitis, sistematis, kritis, dan kreatif serta kemampuan bekerjasama. Kompetensi tersebut diperlukan agar peserta didik dapat memiliki kemampuan memperoleh, mengelola dan memanfaatkan informasi untuk bertahan hidup pada keadaan yang selalu berubah, tidak pasti, dan kompetitif. Standar kompetensi dan kompetensi dasar matematika disusun sebagai landasan pembelajaran untuk mengembangkan kemampuan tersebut. Selain itu dimaksudkan pula untuk mengembangkan kemampuan menggunakan matematika dalam pemecahan masalah dan mengkomunikasikan ide atau gagasan dengan menggunakan simbol, tabel, diagram, dan media lain.

Sejalan dengan kurikulum KTSP, Dokumen kurikulum 2013 (2013:34) dalam kerangka dasar dan struktur kurikulum Sekolah Dasar/Madrasah Ibtidaiyah menyatakan bahwa Kurikulum 2013 bertujuan untuk mempersiapkan manusia Indonesia agar memiliki kemampuan hidup sebagai pribadi dan warga negara yang beriman, produktif, kreatif, inovatif, dan efektif serta mampu berkontribusi pada kehidupan bermasyarakat, berbangsa, bernegara, dan peradaban dunia.

Untuk mencapai tujuan pendidikan tersebut pendidik perlu membekali peserta didik dengan pengetahuan yang membantu siswa berpikir logis dan sistematis sehingga kemampuan berpikir kreatif menjadi sangat penting pada pelajaran matematika.

Kemampuan berpikir kreatif sangat diperlukan oleh siswa mengingat bahwa ilmu pengetahuan dan teknologi berkembang sangat pesat dan memungkinkan siapa saja bisa memperolah informasi secara cepat dan mudah dengan melimpah dari berbagai sumber dan tempat manapun di dunia.

Hal ini mengakibatkan cepatnya perubahan tatanan hidup serta perubahan global dalam kehidupan. Jika para siswa tidak dibekali dengan kemampuan berpikir kritis dan kreatif maka mereka tidak akan mampu mengolah menilai dan mengambil informasi yang butuhkannya untuk menghadapi tantangan tersebut. Oleh karena itu kemampuan berpikir kreatif adalah merupakan kemampuan yang penting dalam mata pelajaran matematika.

Sumarmo (2012:4) mengatakan bahwa "pendidikan matematika pada hakekatnya mempunyai dua arah pengembangan yaitu untuk memenuhi kebutuhan masa kini dan masa datang". Kebutuhan masa kini yaitu kebutuhan yang mengarah pada kemampuan pemahaman konsep-konsep yang diperlukan untuk menyelesaikan masalah matematika dan ilmu pengetahuan lainnya, sedangkan kebutuhan masa datang adalah kebutuhan yang mengarah pada kemampuan nalar yang logis, sistematis, kritis, dan cermat serta berpikir objektif dan terbuka untuk menghadapi masalah dalam kehidupan sehari-hari serta untuk menghadapi masa depan yang selalu berubah.

Pada kenyataanya proses-proses pemikiran tinggi termasuk berpikir kreatif jarang dilatihkan. Pembelajaran matematika di sekolah dasar selama ini lebih menekankan pada hafalan dan mencari jawaban yang benar terhadap soal-soal yang diberikan. Siswono (2008:2) menyatakan bahwa "berpikir kreatif jarang ditekankan pada pembelajaran matematika karena model yang diterapkan cenderung berorientasi pada pengembangan pemikiran analitis dengan masalahmasalah yang rutin".

Melihat kondisi tersebut, penting diadakan pengembangan dan peningkatan mutu dalam pembelajaran matematika yang dapat melatih kemampuan berpikir kreatif siswa melalui pembelajaran salah satunya pembelajaran dengan pemecahan masalah untuk melatih kemampuan berpikir kreatif.

Djamarah (2010:91) menyatakan bahwa “ Pemecahan masalah bukan hanya sekadar metode mengajar tetapi juga merupakan suatu metode berpikir, sebab dalam pemecahan masalah dapat menggunakan metode lain yang dimulai dari mencari data sampai menarik kesimpulan".

Reys (2004:108) menyatakan bahwa "pemecahan masalah dalam pembelajaran matematika merupakan keterampilan yang diperlukan oleh seseorang. Di sekolah, siswa harus memecahkan masalah untuk memahami konsep-konsep matematika, menemukan hubungan baru matematika, dan membuat hubungan matematika dengan mata pelajaran lain. Kedua, anak-anak dan orang dewasa menghadapi masalah matematika 
dalam kehidupan sehari-hari sebagai konsumen, warga negara, dan pekerja."

Pada materi pecahan siswa dapat menemukan banyak alternatif jawaban dan cara penyelesaian, selain itu materi pecahan juga dekat dengan kehidupan sehari-hari siswa sehingga materi ini cocok untuk melatih ketrampilan berpikir dengan menggunakan pemecahan masalah.

Berdasarkan paparan di atas, dapat disimpulkan bahwa mata pelajaran matematika perlu diberikan untuk membekali peserta didik dengan kemampuan berpikir kreatif dan mengembangkan kemampuan menggunakan matematika dalam pemecahan masalah akan tetapi pada kenyataannya pembelajaran matematika di Sekolah Dasar jarang melatihkan kemampuan berpikir kreatif dan kemampuan menggunakan matematika dalam pemecahan masalah sehingga perlu diadakan penelitian untuk mengembangkan perangkat pembelajaran dengan pemecahan masalah untuk melatih kemampuan berpikir kreatif pada materi pecahan di kelas IV SD.

Berdasarkan latar belakang, peneliti mengajukan pertanyaan penelitian sebagai berikut (1) Bagaimana proses dan hasil pengembangan perangkat pembelajaran dengan pemecahan masalah yang layak untuk melatih kemampuan berpikir kreatif kelas IV SD materi pecahan? (2) Bagaimana keefektifan pembelajaran dengan pemecahan masalah untuk melatih kemampuan berpikir kreatif siswa kelas IV SD materi pecahan?

Berdasarkan pertanyaan penelitian di atas, maka tujuan penelitian ini adalah (1) Mendeskripsikan proses dan hasil pengembangan perangkat pembelajaran dengan pemecahan masalah yang layak untuk melatih kemampuan berpikir kreatif siswa kelas IV SD materi pecahan. (2) Mendeskripsikan keefektifan pembelajaran dengan pemecahan masalah untuk melatih kemampuan berfikir kreatif siswa kelas IV SD materi pecahan.

Dalam penelitian ini akan dikembangkan perangkat pembelajaraan yang terdiri dari Rencana Pelaksanaan Pembelajaran (RPP), Lembar Kegiatan Siswa (LKS), dan Penilaian Autentik..

\section{METODE PENELITIAN}

Tujuan pertama penelitian ini untuk mendiskripsikan dan menghasilkan perangkat pembelajaran dengan pemecahan masalah yang layak untuk melatih kemampuan berpikir kreatif siswa kelas IV SD materi pecahan, dengan demikian penelitian ini merupakan penelitian pengembangan, sedangkan tujuan kedua penelitian ini adalah untuk mengetahui keefektifan perangkat pembelajaran dengan pemecahan masalah untuk melatih kemampuan berpikir kreatif siswa kelas IV SD materi pecahan sehingga penelitian pengembangan dilanjut dengan penelitian eksperimen. Dalam penelitian ini tidak semua variabel dapat dikontrol dengan ketat, ada beberapa variabel yang sebenarnya dapat berpengaruh terhadap hasil penelitian tetapi tidak dapat dikontrol secaraa menyeluruh, misalnya keadaaan ekonomi siswa, kesehatan siswa, pendidika orang tua siswa, dan sebagainya. Sehingga penelitian ini digolongkan pada penelitian Quasi Experimental Designs.

Pengembangan perangkat pembelajaran dilakukan untuk menghasilkan perangkat pembelajaran yang terdiri dari Rencana Pelaksanaan Pembelajaran (RPP), Lembar Kerja Siswa (LKS) dan Penilaian Autentik yang layak dan dapat digunakan.

Pengembangan perangkat pembelajaran mengacu pada model $4 D$ yang dikembangkan oleh Thiagarajan, dkk (1974) untuk menghasilkan perangkat pembelajaran dengan pemecahan masalah untuk elatih kemampuan berpikir kreatif siswa kelas IV SD materi pecahan.

Setelah dihasilkan perangkat pembelajaran yang dinyatakan layak dan dapat digunakan kemudian dilanjutkan dengan penelitian eksperimen menggunakan Nonequivalent Control Group Design untuk mengetahui keefektifan perangkat pembelajaran dengan pemecahan masalah untuk melatih kemampuan berpikir kreatif siswa kelas IV SD materi pecahan.

Subjek penelitian pada penelitian pengembangan perangkat pembelajaran ini adalah siswa kelas IV SD Negeri 2 Mudal Kecamatan Mojotengah Kabupaten Wonosobo dengan jumlah siswa 33. Sedangkan untuk penelitian eksperimen dilakukan di SD Negeri 1 Sigedang Kecamatan Kejajar Kabupaten Wonosobo dengan siswa kelas IV A dengan jumlah siswa 29 sebagai kelas eksperimen dan Kelas IV B dengan jumlah siswa 23 sebagai kelas kontrol.

Prosedur pengembangan perangkat dalam penelitian menggunakan model $4 D$ yang dikembangkan oleh Thiagarajan, Semmel \& Semmel (1974) dengan sedikit modifikasi yaitu penyederhanaan yang semula terdiri dari terdiri dari 4 tahap yaitu define (pendefinisian), design (perancangan), develop (pengembangan), dan disseminate (penyebaran). Menjadi 3 tahap hanya sampai tahap develop (pengembangan). 
Tahap define adalah tahap untuk menetapkan dan mendefinisikan syarat-syarat pembelajaran. Tahap define ini mencakup lima langkah pokok, yaitu analisis ujung depan (front-end analysis), analisis siswa (learner analysis), analisis tugas (task analysis), analisis konsep (concept analysis) dan perumusan tujuan pembelajaran (specifying instructional objectives).

Tahap perancangan bertujuan untuk merancang perangkat pembelajaran. Empat langkah yang harus dilakukan pada tahap ini, yaitu: (1) penyusunan standar tes (criterion-test construction), (2) pemilihan media (media selection) yang sesuai dengan karakteristik materi dan tujuan pembelajaran, (3) pemilihan format (format selection), yakni mengkaji format-format bahan ajar yang ada dan menetapkan format bahan ajar yang akan dikembangkan, (4) membuat rancangan awal (initial design) sesuai format yang dipilih

Tahap pengembangan adalah tahap untuk menghasilkan produk pengembangan yang dilakukan melalui dua langkah, yakni: (1) penilaian ahli (expert appraisal) yang diikuti dengan revisi, (2) uji coba pengembangan (developmental testing). Tujuan tahap pengembangan ini adalah untuk menghasilkan bentuk akhir perangkat pembelajaran setelah melalui revisi berdasarkan masukan para pakar ahli/praktisi dan data hasil ujicoba. Langkah yang dilakukan pada tahap ini adalah sebagai berikut (1) Validasi ahli/praktisi (expert appraisal) (2) Uji coba pengembangan (developmental testing) Untuk menjawab rumusan masalah yang kedua maka dilakukan penelitian eksperiimen, rancangan penelitian ini adalah Nonequivalent Control Group Design seperti berikut ini:

Tabel 3.1 Rancangan Penelitian

\begin{tabular}{|l|l|l|l|}
\hline Kelas & $\begin{array}{l}\text { Pretes } \\
\mathrm{t}\end{array}$ & $\begin{array}{l}\text { Perlakua } \\
\mathrm{n}\end{array}$ & $\begin{array}{l}\text { Posttes } \\
\mathrm{t}\end{array}$ \\
\hline $\begin{array}{l}\text { Eksperime } \\
\mathrm{n}\end{array}$ & $\mathrm{T}_{1}$ & $\mathrm{Xa}$ & $\mathrm{T}_{2}$ \\
\hline Kontrol & $\mathrm{T}_{1}$ & $\mathrm{Xb}$ & $\mathrm{T}_{2}$ \\
\hline
\end{tabular}

Keterangan :

$\mathrm{T}_{1}=\mathrm{T}_{2}$ ( butir tes $\mathrm{T}_{1}$ dan $\mathrm{T}_{2}$ adalah sama)

$\mathrm{Xa}$ : Perlakuan pada kelas eksperimen menggunakan pembelajaran dengan pemecahan masalah untuk melatih kemampuan berpikir kreatif siswa kelas IV SD materi pecahan.

$\mathrm{Xb}$ : Perlakuan pada kelas kontrol menggunakan pembelajaran yang biasa dilakukan oleh guru kelas.
Pengumpulan data dalam penelitian ini menggunakan teknik sebagai berikut (1) Validasi (2) Observasi (3) Penyebaran Angket (4) Tes Dalam penelitian ini digunakan instrumen pendukung sebagai berikut. (1) Indikator Kemampuan Berpikir Kreatif (2) Tes Hasil Belajar (3) Lembar Penilaian Autentik (4) Lembar validasi perangkat pembelajaran (5) Lembar pengamatan keterlaksanaan RPP (6) Angket respon siswa (7) Lembar pengamataan aktivitas siswa selama pembelajaran.

Teknik analisis data yang digunakan dalam penelitian ini adalah deskriptif kualitatif dan statistik deskriptif.

Indikator Keefektifan penelitian ini adalah (1) Lembar pengamatan keterlaksanaan RPP minimal berkategori baik dengan nilai $\geq 75$ (2) Angket respon siswa minimal berkategori baik dengan nilai $\geq 75$ (3) Persentase aktivitas siswa $\geq 75 \%$ (4) Kriteria tingkat keberhasilan peningkatan hasil belajar siswa dan peningkatan kemampuan berpikir kreatif siswa adalah jika hasil uji $\mathrm{N}$-gain mencapai kriteria sedang atau tinggi (5) Terdapat perbedaan peningkatan hasil belajar dan kemampuan berpikir kreatif yang signifikan antara kelas eksperimen yang menggunakan pembelajaran dengan pemecahan masalah untuk melatih kemampuan berpikir kreatif dengan kelas kontrol yang menggunakan pembelajaran konvensional berdasarkan hasil analisis data menggunakan SPSS release 20 dengan hasil t hitung $>\mathrm{t}$ tabel.

\section{HASIL DAN PEMBAHASAN}

Tujuan pertama penelitian ini adalah untuk menghasilkan perangkat pembelajaran dengan pemecahan masalah untuk melatih kemampuan berpikir kreatif siswa kelas IV SD materi pecahan yang layak, sedangkan tujuan kedua adalah untuk mengetahui efektifitas pembelajaran dengan menggunakan perangkat pembelajaran dengan pemecahan masalah untuk melatih berpikir kreatif siswa di kelas IV SD materi pecahan

Untuk memenuhi tujuan tersebut, terlebih dahulu dilakukan penelitian pengembangan menggunakan model 4D yang dimodifikasi menjadi 3D dilanjutkan penelitian eksperimen untuk mengetahui efektifitas pembelajaran dengan pemecahan masalah untuk melatih berpikir kreatif siswa di kelas IV SD materi pecahan.

Secara umum semua penilaian validator terhadap perangkat pembelajaran dengan pemecahan masalah untuk melatih kemampuan berpikir kreatif siswa kelas IV SD materi pecahan adalah sebagai 
berikut (1) Nilai rata-rata Validasi RPP 96 dengan kategori sangat baik (2) Nilai rata-rata validasi LKS 86 dengan kategori baik (3) Nilai rata-rata Penilaian Autentik 94 dengan kategori sangat baik, sehingga dapat diambil kesimpulan bahwa perangkat pembelajaran berupa RPP, LKS dan Penilaian Autentik dinyatakan layak dan dapat digunakan untuk ujicoba lapangan.

Ujicoba bertujuan untuk penyempurnaan perangkat pembelajaran (draft III) sebelum perangkat pembelajaran digunakan pada kelas eksperimen.

Adapun subyek ujicoba adalah siswa kelas IV SDN 2 Mudal sebanyak 33 siswa, dengan satu RPP sebanyak 3 kali pertemuan, 60 menit pelajaran untuk pretes dan 60 menit pelajaran untuk postes. Data yang diperoleh berupa data hasil pretes dan pos tes siswa, data pengamatan keterlaksanaan RPP, data angket respon siswa terhadap pembelajaran, dan data pengamatan aktivitas siswa. Data yang diperoleh saat ujicoba ini dianalisis kemudian hasilnya digunakan sebagai bahan pertimbangan untuk merevisi draft III menjadi perangkat pembelajaran yang layak dan dapat digunakan untuk eksperimen.

Kriteria tingkat keberhasilan peningkatan hasil belajar siswa dan peningkatan kemampuan berpikir kreatif siswa adalah jika kriteria $N$-gain mencapai kriteria sedang atau tinggi.

Hasil analisis pretes dan postes hasil belajar memperoleh nilai rata-rata gain 0,7 berkategori tinggi. Sedangkan hasil analisis pretes dan postes peningkatan kemampuan berpikir kreatif memperoleh nilai rata-rata gain 0,4 berkategori sedang. Sehingga hasil belajar dan kemampuan berpikir kreatif siswa dinyatakan meningkat secara signifikan.

Dari hasil analisis penilaian autentik dengan ketuntasan pembelajaran siswa mencapai $97 \%$ dapat diperoleh kesimpulan bahwa perangkat pembelajaran dengan pemecahan masalah untuk melatih kemampuan berpikir kreatif siswa kelas IV SD materi pecahan layak dan dapat digunakan.

Dari hasil analisis data pengamatan di atas diperoleh rata-rata nilai keterlaksanaan RPP selama ujicoba adalah 93,3 berkategori A (sangat baik). Sehingga dapat diambil kesimpulan bahwa kemampuan guru dalam mengelola pembelajaran berkategori sangat baik dan memenuhi kriteria perangkat pembelajaran yang layak.

Berdasarkan hasil data pengamatan di atas diperoleh kesimpulan bahwa hasil Respon Siswa terhadap pembelajaran memperoleh nilai 97 dengan kategori sangat baik sehingga perangkat pembelajaran dengan pemecahan masalah untuk melatih keterampilan berpikir kreatif siswa kelas IV SD materi pecahan dinyatakan layak dan dapat digunakan.

Berdasarkan kriteria aktivitas siswa seperti diuraikan dalam bab III diperoleh kesimpulan bahwa aktivitas siswa selama pembelajaran dikatakan layak dengan rata-rata prosentase aktivitas siswa selama pembelajaran adalah 92\% sehingga perangkat dinyatakan layak dan dapat digunakan.

Berdasarkan hasil pencapaian kriteria perangkat pembelajaran yang layak dapat disimpulkan bahwa perangkat pembelajaran dengan pemecahan masalah untuk melatih kemampuan berpikir kreatif pada materi pecahan untuk siswa kelas IV SD N 1 Sigedang layak dan dapat digunakan.

Untuk menjawab pertanyaan penelitian yang kedua dilakukan penelitian eksperimen di $\mathrm{SD} \quad \mathrm{N} \quad 1$ Sigedang. Adapun subyek penelitian terdiri dari dua kelas pada sekolah yang sama.

Kegiatan eksperimen dilakukan selama 5 hari di SDN 1 Sigedang dengan jadwal kegiatan tercantum pada lampiran. Pelaksanaan pembelajaran di kelas eksperimen sama seperti pelaksanaan pembelajaran di kelas ujicoba, sedangkan pelaksanaan pembelajaran pada kelas kontrol menggunakan pembelajaran seperti biasanya dimana perangkat pembelajaran telah dibuat oleh guru ketika awal semester genap dimulai. Dalam hal ini peneliti tidak melakukan pengamatan pelaksanaan pembelajaran di kelas kontrol sebagaimana yang dilakukan di kelas eksperimen, namun peneliti hanya mengamati untuk melihat apakah benar-benar menggunakan pembelajaran seperti ciri tersebut.

Hasil penelitian yang akan dianalisis secara deskriptif adalah data Keterlaksanaan RPP, respon siswa terhadap pembelajaran pada kelas eksperimen dan tes hasil belajar untuk kedua kelompok.

Berdasarkan kriteria kemampuan guru mengelola pembelajaran dapat disimpulkan bahwa pembelajaran efektif jika lembar pengamatan keterlaksanaan RPP minimal berkategori baik dengan nilai $\geq 75$ dan data dari hasil pengamatan menunjukkan bahwa nilai pengamatan keterlaksanaan RPP 92,5 berkategori sangat baik sehingga perangkat dinyatakan efektif.

Berdasarkan kriteria respon siswa terhadap pelaksanaan pembelajaran dapat disimpulkan bahwa pembelajaran efektif jika angket respon siswa terhadap pembelajaran minimal berkategori baik dengan nilai $\geq 75$ dan data dari hasil 
pengamatan menunjukkan bahwa nilai siswa terhadap pelaksanaan pembelajaran 94,6 berkategori sangat baik sehingga perangkat dinyatakan efektif.

Berdasarkan kriteria aktivitas siswa diperoleh kesimpulan bahwa aktivitas siswa selama pembelajaran dikatakan efektif jika rata-rata hasil pengamatan minimal berkategori baik dengan nilai $\geq 75 \%$ dan data dari hasil pengamatan menunjukkan bahwa rata-rata prosentase aktivitas siswa selama pembelajaran adalah 90 sehingga perangkat dinyatakan efektif.

Analisis Uji $t$ untuk pretes hasil belajar menunjukan $\mathrm{t}$ hitung $=-0,811$ dan pretes kemampuan berpikir kreatif menunjukan $\mathrm{t}$ hitung $=$ 0,604. Sedangkan t tabel. untuk df 50 dengan tingkat kepercayaan 95\% adalah 2,009 dengan demikian $\mathrm{t}$ hitung pretes hasil belajar dan t hitung kemampuan berpikir kreatif siswa $<$ dari $\mathrm{t}$ tabel.yang berarti tidak ada perbedaan yang signifikan antara pretes hasil belajar dan kemampuan berpikir kreatif siswa antara kelas kontrol dan kelas eksperimen.

Analisis Uji $\mathrm{t}$ untuk postes hasil belajar menunjukan $\mathrm{t}$ hitung $=3,637$ dan postes kemampuan berpikir kreatif siswa menunjukan $\mathrm{t}$ hitung $=6,680$. Sedangkan t tabel. untuk df 50 dengan tingkat kepercayaan 95\% adalah 2,009 dengan demikian thitung postes hasil belajar siswa dan $\mathrm{t}$ hitung kemampuan berpikir kreatif siswa $>$ dari t tabel.yang berarti ada perbedaan yang signifikan antara postes hasil belajar dan kemampuan berpikir kreatif antara kelas kontrol dan kelas eksperimen.

Hasil analisis $\mathrm{N}$-gain untuk pretes dan postes hasil belajar kelas eksperimen memperoleh nilai rata-rata gain 0,7 mendapat kategori tinggi dan hasil analisis $N$-gain untuk pretes dan postes peningkatan kemampuan berpikir kreatif memperoleh nilai ratarata gain 0,43 berkategori sedang. Sedangkan Hasil analisis pretes dan postes hasil belajar kelas kontrol memperoleh nilai rata-rata gain 0,3 berkategori sedang dan hasil analisis pretes dan postes peningkatan kemampuan berpikir kreatif memperoleh nilai rata-rata gain 0,1 berkategori rendah. Sehingga dapat diambil kesimpulan peningkatan hasil belajar dan kemampuan berpikir kreatif kelas eksperimen meningkat secara signifikan dibaandingkan kelas kontrol.

Berdasarkan temuan diatas dapat disimpulkan bahwa pembelajaran dengan pemecahan masalah untuk melatih kemampuan berpikir kreatif efektif pada materi pecahan untuk siswa kelas IV SD Negeri I Sigedang Kecamatan Kejajar Kabupaten Wonosobo.

\section{Simpulan dan Saran}

Berdasarkan hasil analisis data dan pembahasan hasil penelitian yang telah diuraikan dapat disimpulkan bahwa pengembangan perangkat pembelajaran dengan pemecahan masalah untuk melatih kemampuan berpikir kreatif siswa kelas IV SD materi yang terdiri dari 1 buah RPP, 3 buah LKS, dan instrumen penilaian Autentik dinyatakan layak dan efektif untuk meningkatkan hasil belajar dan kemampuan berpikir kreatif siswa kelas IV SD materi pecahan.

Berdasarkan hasil penelitian ada beberapa saran yang dapat peneliti kemukakan antara lain (1) Bagi guru, perangkat pembelajaran dengan pemecahan masalah untuk melatih kemampuan berpikir kreatif siswa dapat digunakan sebagai alternatif perangkat untuk mengajar matematika materi pecahan. (2) Bagi peneliti yang berminat mengembangkan perangkat pembelajaran dengan pemecahan masalah untuk melatih kemampuan berpikir kreatif siswa pada materi, mata pelajaran atau kelas yang lain penelitian ini dapat dijadikan acuan untuk penelitian tersebut.

\section{DAFTAR PUSTAKA}

Al-Khalili, Amal A. (2005). Mengembangkan kreativitas Anak (Diterjemahkan oleh Ummu Farida). Jakarta Timur: Pustaka AL-Kautsar.

Arends, R. I. 2012. Learning To Teach, Sixth Edition. New York: McGra Hill.

As'ari, A.R. (1992). Kegiatan Pemecahan Masalah dalam Pembelajaran Matematika. Majalah Eksakta.

Depdiknas. (2006). Kurikulum Tingkat Satuan Pendidikan Sekolah Dasar/Madrasah Ibtidaiyah. Jakarta: BNSP.

Depdiknas. (2013). Dokumen Kurikulum 2013 Sekolah Dasar/Madrasah Ibtidaiyah. Jakarta: CV Sahabat.

Djamarah, S. B. \& Zain, A. (2010). Strategi Belajar Mengajar. Jakarta: Rineka Cipta.

Haylock, Derek. (1997). Recognising Mathematical Creativity in Schoolchildren. 
http://www.emis.de/journals/ZDM/zdmg73a 2.pdf. Diakses tanggal 2 Januari 2014.

Heruman. (2007). Model pembelajaran Matematika di Sekolah Dasar. Bandung: Remaja Rosdakarya.

Hudojo, H. 1983. Pemecahan Masalah dalam Pengajaran Matematika. Jakarta: Jakarta Depdibud Dikti P2LPTK.

Ibrahim, Muslimin. (2001). Model Pengembangan Perangkat Pembelajaran Menurut Jerold E. Kemp \& Thiagarajan. Surabaya: PSMS-PPs Unesa.

Izzati, N. (2009),Berpikir Kreatif dan Kemampuan Pemecahan Masalah Matematis: Apa, Mengapa, dan Bagaimana Mengembangkannya Pada Peserta Didik. Prosiding Seminar Nasional Matematika dan Pendidikan Matematika, Bandung 19 Desember 2009, hal. 49-60

Kennedy, L.M. \& Tipp, S. (1994). Guiding Children's of Learning of Mathematics. Belmont, California: Wadworth Publishing Company.

Munandar, Utami. (1999). Kreatifitas dan Keterbakatan. Jakarta: Gramedia Pustaka Utama.

Morrison, G.R., Ross, S.M., Kalman, H.K., \& Kemp, J.E. (2011) Designing Effective Instruction Sixth Edition. Hoboken: John Willey \& Sons, Inc.

NCTM. (2010). Why is Teaching With Problem Solving Important to Student Learning? Brief. www.nctm,org/news/content.aspx $? \mathrm{id}=25713$ . Diakses tanggal 2 Desember 2014.

Nieven, Nienke. Dkk (1999) Design Approaches and Tools in Education and Training. Kluwer Academic Publisher.

Reys, Robert. Dkk (2004). Helping Children Learn Mathematics (9th edition). John Wiley \& Sons, Inc.
Ruseffendi, ET. (1991). Pengantar kepada Membantu Guru Mengembangkan Kompetensinya dalam Pengajaran Matematika melalui CBSA. Bandung: Tarsito.

Siswono, Tatag Y.E. (2007). Penjenjangan kemampuan berpikir kreatif dan identifikasi tahap berpikir kreatif dalam memecahkan dan mengajukan masalah matematika. Disertasi: Unesa Surabaya.

Siswono, Tatag Y.E. (2009). Pembelajaran matematika berbasis Pengajuan dan Pemecahan Masalah untuk Meningkatkan Kemampuan Berpikir Kreatif. Surabaya: Unesa University Press.

Slavin, R.E. (2006) Educational Psycology Theory and Practice Eighth Edition. Boston: Allyn \& Bacon.

Sumarmo, U. (2012), Bahan Belajar Mata Kuliah Proses Berpikir Matematik Program S2 Pendidikan Matematika. STKIP Siliwangi Bandung.

Thiagarajan, S., Semmel, S.D., \& Semmel, M. I. (1974). Instructional Development for Training Teachers of Exceptional Children. Bloomington Indiana: Indiana University.

Torrance, E, Paul. (1976). Guiding Creative Talent. New York: Robert E Krieger Publishing Company.

Polya, G. (1973) How to solve it: A New Aspect of Mathematical Method. Second Edition. New Jersey: Princeton University Press.

Pehkonen, Erkki (1997). The State-of-Art in Mathematical Creativity. http://www.fiz.karlsruhe.de/fiz/publications/ zdm ZDM volum 29 (june 1997) Number 3. Electronic Edition ISSN 1615-679X. Diakses tanggal 26 November 2014.

Wardani I.G. A.K, dkk. (1997). Prosedur Penelitian. Jakarta: Rineka Cipta. 